\title{
Times of Work and Social Life: Bangladeshi Migrants in Northeast Italy and London
}

(C) The Author(s) 2020 Article reuse guidelines: sagepub.com/journals-permissions DOI: $10.1177 / 0197918320927012$ journals.sagepub.com/home/mrx @SAGE

\section{Russell King}

University of Sussex, Brighton, UK

\section{Francesco Della Puppa}

Laboratory of Social Research - Ca' Foscari University in Venice, Venice, Italy

\begin{abstract}
Taking inspiration from renewed scholarly interest in the role of time in migration, we compare the temporalities of work and social life among male Bangladeshi-origin migrants in northeast Italy and London. We draw conceptually on time geography and rhythmanalysis, and empirically on interviews with 40 Bangladeshi migrant men, to demonstrate the stark contrasts in migrants' daily lives in the two settings and the impacts of moving from northeast Italy to London. More broadly, this article contributes to debates on the temporalities and rhythms of migrants' everyday lives via comparative analysis. While in both settings capitalism inexorably shaped class dynamics through its command over flexible labor, there were also marked differences in the routinization of migrants' work and social and family life. In northeast Italy's small industrial towns, stable shift-based working rhythms created regular free time for family and associative life. In London, where participants' employment was limited to low-skill jobs with unsocial hours, family and social life was disrupted, with consequential effects on social integration. The findings presented here highlight the under-appreciated role of onward migration in global migration dynamics and underscore the importance of time, in particular the way in which the diverse
\end{abstract}

\section{Corresponding Author:}

Francesco Della Puppa, Laboratory of Social Research - Ca' Foscari University in Venice, Dorsoduro 2530, Venice, 30123, Italy.

Email: francesco.dellapuppa@unive.it 
temporalities of migrants' daily lives are shaped by the mode of regulation of the labor market and the spatial setting where migrants' working and social lives unfold.

\section{Keywords}

Bangladeshi migrants, onward migration, time geography, rhythmanalysis, Italy, London

\section{Introduction}

Migration has generally been viewed as a spatial process (e.g., Boyle, Halfacree, and Robinson 1998, 5), meaning that the role of time is implicit; yet time is also indelibly inscribed into the socio-political constructions and personal experiences of migration and (im)mobility (Cwerner 2001; Griffiths, Rogers, and Anderson 2013). The temporalities and rhythms of migrants' everyday lives have rarely been studied in detail, especially in a comparative perspective. This article addresses this gap and contributes to the ongoing theoretical debate on the temporalities of migration (e.g., Mavroudi, Page, and Christou 2017). In particular, we use the notion of "rhythm" as an anchoring concept that brings together mobility and the underlying forces that order and disrupt everyday lives and spaces (Wee, Goh, and Yeoh 2020, 111).

We analyze the rhythms of work, family, and social life among Bangladeshi migrant men in two contrasting settings: northeast Italy and London. The link between these two destinations is "onward migration"- the growing tendency for migrants to engage in multi-stage migration trajectories that question the conventional framing of migration as a bipolar move from origin to destination (King and Karamoschou 2019). In our study, we found that many Bangladeshi men who had been living and working in Italy for a sufficient length of time to acquire Italian citizenship (hence, we call them "Italian-Bangladeshis") undertook a second migration to London, where they and their families joined the largest community of Bangladeshi-origin people outside their home country (Gardner 2002). To be more precise, we focus on Bangladeshi "first-migrant" men who achieved family reunification with their wives and children in Italy, and mainly fulfilled the role of family breadwinners, whether they stayed in northeast Italy or onward-migrated to London.

Our broader theoretical ambition is to demonstrate how an analysis of the temporalities of migration and of migrants' life rhythms exposes the stark contrasts between capitalism's different labor regimes in different geographical settings. We unpack this general aim to highlight three context-specific, yet closely interrelated, issues that our empirical evidence seeks to illuminate. The first asks how daily relationships - at work, within the family, and with colleagues and friendsare transformed by onward migration between two very different labor regimes. Male migrants moved from the regulated working conditions of northeast Italy's Fordist industrial complex and post-Fordist subcontracting small factory units 
(Dunford and Greco 2006) to London's highly deregulated labor market and lowwage tertiary sector linked to strong occupational polarization and the "new migrant division of labor" (Wills et al. 2010). The second issue we address compares and contrasts the spatiality of daily life for migrant Bangladeshi men in the "diffuse urbanization" of small towns and industrial villages in northeast Italy (Della Puppa and Gelati 2015) with London's sprawling mega-region as a "global city" (Sassen 1991). Third and finally, we address the differentiated impact of migration and its temporalities with respect to inter-generational prospects, reflecting the fact that onward migration may be motivated not so much by immediate gains for firstgeneration migrants but by the future life-chances of the second generation.

This article can be conceptually located with reference to two important trends in the study of global migration. First, Bangladeshi migration to Italy is a good example of Winders's (2014) "new immigration destinations in a global context," whereby international migration's spatial dynamics have shifted from traditional channels and gateways, defined by geographical proximity, colonial history, and trading ties, to new opportunities related to porous borders and more complex migration and lifecourse trajectories. At the same time, our research material speaks to certain constants in contemporary capitalism, class dynamics, and flexible labor and to the ways in which migrants are inserted into the diversified socio-economic urban fabrics of European and global labor markets. Italy, with its rather lax regime of border control (especially during the 1980s and 1990s), offered Bangladeshi migrants a foothold in Europe.

The second trend in contemporary global migration dynamics to which we contribute is onward migration, which we use as a temporal frame to structure this article's comparative aspect. There is a substantial emerging literature on this phenomenon, both within North America (e.g., King and Newbold 2007) and more particularly in Europe, where the variety of onward pathways is much greater (e.g., Ahrens, Kelly, and van Liempt 2016; King and Karamoschou 2019). As we shall see, Bangladeshi onward migration to the United Kingdom, as well as being driven by conventional push-and-pull factors, was above all facilitated by many Bangladeshis' acquisition of citizenship in Italy.

To develop these ideas, the article proceeds as follows. The next section reviews the key intersections of the time-migration nexus, highlighting time geography, rhythmanalysis, and other "timings" of migration. Then we briefly document the evolution of Bangladeshi migration to Italy and the United Kingdom. A methodology section follows and describes the main research technique of in-depth interviews. The article's empirical heart contains three sections. First, we review participants' reasons for onward-migrating from northeast Italy to London, which have mainly to do with the "future time" of their children, for whom London is thought to offer better education and career opportunities. The other two sections describe and comparatively analyze the temporalities of work, family, and social life in the two migration settings. In Italy, we find that the legalization of irregular status, family reunion, regular factory work, and an integrated and temporally well-ordered 
social life within the ethnic community, and to some extent also with local Italians, gave Bangladeshi men in this study a measure of economic security and life satisfaction, but that this stability was tempered by a desire to escape from dead-end factory work and to give their children a better long-term future. By contrast, in London, onward migrants were subjected to a more variable life rhythm, doing precarious jobs at unsocial hours in the city's ethnicized low-wage economy and making it difficult to sustain a satisfactory family and social life. Hence, their hopes were pinned on the next generation's future success, rather than on their own lessthan-ideal work and social/family life arrangements. The concluding discussion highlights the article's key findings and elaborates some theoretical implications.

\section{Conceptual Foundations: Time Geography and Rhythmanalysis}

As has long been acknowledged (e.g., Malmberg 1997), migratory phenomena unfold in space and in time. Recently, there has been increased scholarly interest in the intersections of time and temporalities with migration and mobility studies (Cojocaru 2016; Griffiths et al. 2013; Mavroudi et al. 2017; Robertson 2015). The theoretical roots of this approach can be found in pioneering writings on time geography by Hägerstrand $(1975,1985)$, in which he traced time-paths across a range of temporal scales from a single day to a lifetime. According to Thrift and Pred (1981, 277), Hägerstrand's time geography offered "a discipline-transcending perspective on the everyday workings of society and the biographies of individuals." Hägerstrand's engagement with long-distance migration was limited, but his mapping of the "choreography" of daily existence (Pred 1977) foreshadowed our analysis of the temporalities of migrants' daily lives.

Hägerstrand showed that the individual's path through time and space is closely related to one or more "projects" in which he/she is engaged, such as the need to secure work or to find a better future for one's children. Some of these projects are strongly tied to specific places, while others are easily transferable from place to place. Equally important, there are instances when these goals or projects can only be achieved elsewhere, through migration (Malmberg 1997). This latter circumstance applies to our study of Bangladeshis onward-migrating from Italy to the United Kingdom to fulfil the "project" of offering their children better education and career prospects.

Furthermore, Thrift and Pred pointed out how the time-geographic concepts of path and project can provide researchers pursuing a mode-of-production analysis with a concrete means of linking the workings of economic systems with the everyday social activities and relations of people $(1981,279)$. Pred's (1981) study of the individual life consequences of the rise of factory and workshop production in nineteenth-century US cities is a good example, as is Glennie and Thrift's (2009) more detailed historical analysis of the evolution of "clock time" and "social discipline" in "shaping the day" in England and Wales. Building on the pioneering 
paper by E.P. Thomson (1967) on time, work discipline, and industrial capitalism, their use of time geography provided new insights into the ways in which tightly synchronized production regimes imposed "time discipline" and led to a modification in the nature of family and social life.

Returning to Hägerstrand's work, his semi-autobiographical 1982 paper, based on recollections of his early life in a Swedish village, recalled the community's "halting rhythmicity" - the daily, weekly, and seasonal rhythms of farmers tending their fields and animals; the village foundry and metal workshop, with its daily ebb and flow of workers; the school with its own daily and holiday rhythms; and the aural rhythms of the timetabled passing of trains and tolling of church bells. This attention to the intimate workings of time across the rhythm of a community clearly resonates with Lefebvre's rhythmanalysis, even if the two authors did not crossreference each other. In the subtitle to his book Rhythmanalysis, "Space, Time and Everyday Life," Lefebvre (2004), for example, signals his project's potential, which is "the interrelation of understandings of space and time in the comprehension of everyday life" (Elden 2004, vii). Lefebvre's Rhythmanalysis says little about migration per se, but scholars studying migration and its associated mobilities have recently begun to apply his typology of rhythms to real-life situations of migrants and mobile people, including young people and students (Marcu 2017), domestic and care workers (Wee et al. 2020), rural farm laborers (Reid-Musson 2018), and to various spatial settings, including islands (King and Lulle 2015) and borders (Novak 2017).

The examples given earlier demonstrate a fundamental principle of rhythmanalysis: the triadic relationship between space/place, time, and energy that sets people in motion. Their movements are not casual or random; they are driven by the dictates of work, family relations, social life, emotions, the desire to travel, and so on. As Edensor (2010) points out, places and spaces become distinctive through their ensemble of intersecting rhythms-polyrhythms in Lefebvre's typology (2004, 67-68). A typical polyrhythmic setting would be the home-village observed by Hägerstrand (1982): a somewhat bucolic and timeless beat of several spatiotemporal and aural rhythms apparently in harmony with one another. Where the system is in stable good health, Lefebvre describes it as eurythmic. However, when the various rhythms of work, family, community, and so on are discordant, we arrive at a state of arrhythmia, of malfunction or breakdown.

Acknowledging that, especially in Anglo-American critical social science, an "academic industry" on Lefebvre has developed (Kipfer et al. 2008, 5), we note that Rhythmanalysis, possibly the most eccentric of Lefebvre's many books, is rooted in the author's Marxist critique of capitalism, particularly his interlinked and wideranging analyses of labor relations, class, urbanization, space, time, and everyday life (see Lefebvre's main English translations: 1991, 1996, 2014). Across his writings, Lefebvre was concerned with the relationship between the capitalist system and individuals' daily lives (Elden 2004, xv). As he stated in no uncertain terms (Lefebvre 2004, 51-55), 
Capitalism makes masters and slaves, the rich and the poor, the propertied and the proletariat ... Capital has something more than maliciousness ... It kills nature ... . It kills the town... it kills artistic creation.... It delocates humans .... Capital kills social richness. It produces private richness .... The rhythm [of] capital is the rhythm of producing (everything: things, people) and destroying (through speculation ... brutal intervention etc.).

Hence, to quote Meyer $(2008,151)$, capital's destructive role consists in its "imperious contempt for the body and lived-time." As Smith and Winders (2008) have noted in the post-Fordist context of Latino migrants in the US South, migrant bodies tend to be young, male, mobile, available wherever needed, cheap, productive, and disposable. And as several writers on migration and rhythmanalysis have made explicit, control over time is central to the operationalization of power, especially by employers (Griffiths et al. 2013; Marcu 2017; Reid-Musson 2018; Wee et al. 2020). Intensive agriculture, artisan workshops, large factories, tourism, and street-hawking all have differentiated daily, weekly and seasonal rhythms, which are, in turn, related to broader modes of economic regulation, such as industrial capitalism, neoliberalism, the informal economy, and so on. For the ItalianBangladeshi participants in our research, these disciplining structures and rhythms were the stuff of their everyday lives, whether as factory shift-workers in northeast Italy or as on-call minicab drivers in London.

\section{Bangladeshis in Italy and London: Migrants and Citizens}

This article's comparative analysis of Bangladeshi migrant men's work experiences and social lives in two distinct spatio-temporal contexts is not a conventional bilateral comparison between parallel migration streams issuing contemporaneously from a common source. Instead, the presence of Bangladeshi-origin migrants in the two destinations arises through more complex historical temporalities produced by onward migration. We, therefore, undertake the diachronic analysis of changes in the rhythms of everyday life - which take shape from the interweaving of family and migratory cycles - observed at different times within participants' biographies.

London's Bangladeshi community has a long history. ${ }^{1}$ Initial rapid growth occurred in the late-nineteenth and early-twentieth centuries, when Bengali seamen recruited by the East India Company from Sylhet, then in British India, began settling in East London's dockyard areas. The community expanded further in the early post-war decades, stimulated by the 1948 Nationality Act, which permitted free entry to the United Kingom for citizens of the (former) colonies. At this stage, most Bangladeshi migrants in London were single men. A new phase started in the 1960s, however, when laws were passed to control new immigration — notably, the

\footnotetext{
${ }^{1}$ This chronology is drawn from Adams (1987) and Gardner (2002).
} 
Commonwealth Immigration Act of 1962 and the Immigration Act of 1971. As a result of this legislative shift, most Bangladeshis in the United Kingdom opted to stay and, as British citizens, pursued a strategy of marriage migration or, if already married, of family reunification (Gardner 2006). By the 2011 British census, the Bangladeshi-origin community in the United Kingdom numbered 447,200, with half this number resident in London (Zeitlyn 2016).

Bangladeshi migration to Italy is much more recent (Priori 2012) and illustrates how, after the 1980s, new "gateways" into Europe opened up for migrants coming from "non-traditional" origins - sending countries with no prior links through colonial history or language affinity to the destination country. In the connection between Bangladesh and Italy, the supply chain lay not in Sylhet and seamen, but in central Bangladesh, including the capital Dhaka, and urban middle-class migrants (Knights and King 1998). The first Bangladeshi immigrants to Italy arrived in the 1980s, due to the closure of borders of other European countries (Priori 2012), making this migration "opportunistic" (King and Knights 1994). Hence, not only did "new" migrants arrive from Bangladesh, but also Bangladeshis already living in other European countries, notably France and Germany, came to Italy, pulled by the attraction of periodic amnesties for irregular migrants to legalize their status. It is important to highlight that the first wave of Bangladeshis arriving in Italy was almost entirely composed of men. Therefore, subsequent family reunions were configured exclusively as "male-led" reunifications (Priori 2012).

During the 1980s and 1990s, Bangladeshi migrants to Italy were heavily concentrated in Rome, where they worked in the city's extensive informal economy as street-hawkers or in catering and other tourism-related services (Knights and King 1998). Subsequently, having obtained legal residence through one of Italy's amnesties, migrants dispersed to other parts of the country, especially the prosperous northeast, where they found factory work and affordable housing and created their own "bangla-towns" (Della Puppa and Gelati 2015). By 2016, the Bangladeshi community in Italy had grown to 122,400 , with major concentrations in Rome and the Veneto region (Centro Studi e Ricerche IDOS 2017).

Thanks to their employment as factory workers in northeast Italy's then-thriving industrial districts and to relatively spacious housing available for rent or mortgage (granted by banks on the basis of stable employment), Bangladeshi men met the criteria for family reunification or marriage migration. However, family reunification had sharply gendered emotional meanings. While already-settled Bangladeshi men were able to (re)construct their emotional universe of family togetherness by bringing their wives and children to Italy, for the reuniting women, it was an "imposed" migration that forced them to abandon their kinship and relational networks in Bangladesh and to suffer the social and emotional downgrading of Southto-North "trailing spouse" or arranged marriage migration (Della Puppa 2018).

Given the gendered nature of Bangladeshi migration to Italy, Bangladeshi men were the first to become eligible, after 10 years of continuous residence, for Italian citizenship, which could then also be claimed by their wives and children (Della 
Puppa and Sredanovic 2017). For some Bangladeshis, possession of an Italian passport represented the last stage in their attempt to stabilize themselves in Italy. For others, it was a strategic step to further mobility, since, as European Union (EU) citizens, they could relocate anywhere within EU territory. Our interviews with community leaders indicate that the vast majority who onward-migrate from Italy go toward the United Kingdom, for reasons that will be clarified presently. According to estimates of the Bangladeshi Embassy in Italy, about 6,000 ItalianBangladeshi families have moved to the United Kingdom since the early 2010s. Counting each family as four members, this number $(24,000)$ represents a notinsignificant share of all Bangladeshis enumerated in Italy $(122,400)$.

Onward migration to the United Kingdom started around 2010, spurred by the temporal coincidence of several factors (Della Puppa and Sredanovic 2017). First, many first-generation Bangladeshis and their families acquired Italian citizenship around this time, giving them a "European" passport. Second, in this period, the economic crisis took hold in Italy; job opportunities were squeezed by factory closures and their negative impact on northeast Italy's regional economy (Sacchetto and Vianello 2016; Veneto Lavoro 2012; 2014). Third, Bangladeshi families saw a grim future for their children in an Italy afflicted not only by ongoing recession but also by prejudice against young people of color. Fourth, many Bangladeshis share a kind of imperial nostalgia that sees London as both the capital of Empire and the capital of the Bangladeshi diaspora. As our field interviews reveal, many research participants were initially oblivious to the harsh realities of immigrant life in London.

\section{Methods and Research Design}

Empirical data for this article derive from 40 in-depth interviews with ItalianBangladeshi men in northeast Italy (20) and London (20). The former group were long-term residents in Italy and had acquired Italian citizenship; many were talking about or actively preparing to move to London. The latter group had already made the move, following a period of residence in Italy that varied between 15 years and 25 years. The interviews were conducted during two phases of fieldwork: in Italy during 2010-11 and in London in 2015-16. Some of those interviewed in London had also been interviewed in Italy five years earlier, allowing us to reconstruct their biographies and better highlight changes in their rhythms of work and social life experienced in the different times and places.

All interviewees were male family breadwinners engaged in paid employment and aged in their $30 \mathrm{~s}, 40 \mathrm{~s}$, or $50 \mathrm{~s}$. We consciously focused on male respondents and their narrated experiences because we wanted to analyze the changes in daily work rhythms and other temporalities of those who had the role of family breadwinner. This perspective has its limitations, as has been widely discussed by other researchers who privilege male testimonies yet also observe gendered experiences of migration (Donaldson et al. 2009; Gallo and Scrinzi 2016; Wojnicka and Pustulk 2019). 
We made a reflexive effort to take into account our own gender positioning in the field, remaining sensitive to gender dynamics in the ensuing analysis, albeit based on male participants' direct voices.

Interviewees were accessed via a variety of initial approaches - through keyinformant representatives of ethnic associations, friendship networks, and more casual contacts - and then supplemented by snowballing. As is typical with this kind of qualitative research, our research participants cannot be considered a true random sample. In interviews, we stressed a dialogic approach, using a flexible interview schema through "generative" questions (Becker 1998) that allowed process to emerge, rather than mere information, and often started from the narration of concrete episodes. According to this approach, we avoided evaluative questions (such as "why?"- a word Becker advocates banning), as they can be deemed threatening and result in defensive answers.

Although interviews were deliberately carried out in a relaxed conversational style to build trust and enhance information flow, they aimed at gathering data on a series of pre-determined themes: social background in Bangladesh and social positioning in Italy (and in London for onward migrants); motivations and strategies underpinning the move (actual or potential) to London; everyday life and the nature of personal, family, working, and leisure life in Italy (and London); and future plans. Interviews were conducted in Italian or English, according to interviewees' preferences, as all participants were fluent in one or both languages.

Interviews were recorded, subject to participants' consent, fully transcribed, and, if in Italian, translated into English. Repeated reading and annotation of interview transcripts were followed by coding of the various thematic segments pertinent to this article's subject and then by an integrated comparative analysis of the "times of work and social life." All participants have pseudonyms.

\section{Motives for Onward Migration}

Having migrated once as younger men, onward-migrants now moving with their families often have more complex and multiple reasons to migrate, as the literature reviews of Ahrens et al. (2016) and King and Karamoschou (2019) reveal. Unsurprisingly, such interwoven motives for onward migration were evident in participants' narratives and reflected a number of economic, social, and cultural-religious factors that are mutually reinforcing and the product of personal circumstances, collective histories, and idealized representations of the British post-imperial context (Hansen 2014). Above all, the move to London was strongly influenced by the "future times" of the next generation - participants' Italian-born children. In Hägerstrandian terms, the "path" led to London in order to realize the "project" of a better life for the children.

In interviewees' perceptions, life in Italy would entail the likelihood that their children retraced the same occupational and existential trajectory that they themselves had followed: that of a generic "migrant worker" locked into subordinate 
sectors of the labor market. This eventuality was perceived as even more likely because of the economic retrenchment that has afflicted Italy for the past decade. This extract from an interview with Apnan in London, where he had recently moved following nearly 20 years in Italy, is typically revealing about how he viewed his son's future, had they remained in Italy.

If he did university there [in Italy], and graduated, where does he work? In a bank? In insurance? At the university, as a researcher, like you? Imagine he tries to get a job in a bank: let's say that among ten white applicants, he is the son of a Bangladeshi immigrant - what chance would he have to be hired, and then to make a career? Maybe you think I'm biased, but I speak of my own experience. In Italy it is like this. Then I asked myself: "But why did I do all this work, as a street vendor, in the restaurants, in the factory, only to see my son do the same work as his father?" .... One day, Italy might change ... but not yet.

Lest this quote be seen as a patrilineal perspective on the second generation's future prospects; other interview data revealed that investment in children's education was broadly gender neutral. In Sayed's words:

Our hope is always higher education for our children, that they do "high" studies at school and university, to become a great engineer, a great doctor or lawyer.... This is our hope, both for my son and my daughter. I was a factory worker, but my children should not do the job that their father did.

London's perceived attractiveness for investing in children's future had several dimensions. One was an education and socialization in English. Many fathers spoke about the way in which socioeconomic opportunities for their children could only be maximized through fluency in English and with academic credentials from the British higher education system. Sherif, interviewed in London after more than 20 years in Italy, put the comparison in the following terms:

Our children were studying in Italy only in the Italian language. The Italian education system ... is a problem for our community .... It is better for our children to study in the UK and then to work there, or in America, or anywhere .... To have better opportunities, English is important for us.

A second argument framing participants' decision to transfer their families from Italy to London was the British capital's specific appeal in Bangladeshis' postcolonial imaginary (Hansen 2014). Two aspects of London's historical and contemporary social geography are relevant here. The first was its historical role as capital of the British Empire and, therefore, repository of values and institutions nostalgically considered still to exist. The second was its contemporary character as a global and cosmopolitan city that, precisely because of its colonial past and long tradition of immigration, now presented itself as a city of multicultural tolerance and diversity 
where national origin, "race," and religious belief did not constitute sources of discrimination or stigma. Among the values frequently referenced by participants were meritocracy and lack of prejudice, especially in the job market. In the words of Kobir, a participant interviewed in both Italy and London,

In the UK there are no differences, I mean inequalities, because of your color. In Italy when I go for a job, the first thing that people see is the color of my skin, so we are always the second choice. While here [in London], they don't look at these things: they look at your experience. "Are you qualified? OK, you can have this job."2

Third, London hosts the largest community of Bangladeshi-origin migrants and their descendants outside Bangladesh and has done for many decades (Gardner 2002; Zeitlyn 2016). Thus, London, especially working-class East London, was perceived as a small version of Bangladesh, where it was possible to "feel at home" and to live in accordance with what participants defined as a "Bengali culture and lifestyle," which included greater freedom to practice Islam. In the quote here, Adnan (London) drew a distinction between the very different histories of Bangladeshi migration and settlement in Italy and England:

We [Bangladeshis] came only recently to Italy ... so we are not a strong community there, whereas here in England, we are a big community, we are already at the third and fourth generations. This means that there are more advantages for us - our compatriots, our community, our food, our language, our culture, everything.... Here, I feel more comfortable, more at home.

Fourth, a driving force in London-bound onward migration was the first generation's desire to escape dead-end factory work and achieve greater upward mobility for themselves. Although this upward trajectory often became a dashed hope, there was also a realization that in Italy "being Italian" on paper did not protect them from the discrimination, inequalities, and rigidities that they experienced on a daily basis in the Italian labor market, where they were confined to the most dangerous and boring jobs on the production line or in other manual employment. Furthermore, the United Kingdom was perceived as a more attractive country because of its more inclusive and transparent welfare system. In the words of Mukul, who had recently relocated to London after twenty years in Italy,

In Italy, if you have a wife and children, and you lose your job, what can you do? Here, if you lose your job, you go to the council, and they help you with bills, the rent .... In Italy, I asked repeatedly to get public housing; the answer was "No ...no...no."

${ }^{2}$ This rosy assessment of migrant life in London may appear justifiable in comparison to the situation in Italy, but we need to acknowledge research that shows that, in London, too, the labor market is racially segmented (e.g., Wills et al. 2010). 
Whilst here, as soon as I arrived, I asked ... and they gave accommodation to me and my family after fifteen days.

A final reason for London-bound onward migration reflects the agency of Bangladeshi reunited wives in Italy and their dissatisfaction with their lives there. Unable to find jobs in the male-dominated industrial economy, they aspired to escape the loneliness and frustration configured by an imposed migration and imagined London as a place where they would have better employment opportunities and a more congenial social life among the city's large Bangladeshi community. We acknowledge that, in our research, women's perspectives are filtered through their husbands' narratives, as in the case of Zaeed, interviewed in northeast Italy, where he had been living for 25 years, but the pattern of Bangladeshi women encouraging onward migration to London was noticeable:

I would like to stay here, but she [referring to his wife] says I have to go there [to London] with the whole family .... I have a permanent job here, everything ... everybody knows me, I am well-known in my community .... There, I don't know what I will find ... it's a new place for me, I don't know anyone, and I'll have to start all over again. She always tells me we have to make sacrifices, always sacrifices, for the children and the family.

The combination of factors outlined in this article acted to produce onward migration but also resulted in unexpected repercussions both on participants' socioeconomic status and day-to-day work and on their family and social lives. We now proceed to a comparative analysis of these temporal rhythms of everyday life, taking in turn the Italian and London contexts.

\section{Times of Work and Social Life in Italy}

The temporal rhythms of work, personal, and family life in Italy evolved over two main stages corresponding to a change in Bangladeshis' geographic settlement pattern and civil status - an initial concentration in Rome, where they worked as single men mainly engaged in street-selling, and then a transfer to northeast Italy's expanding industrial economy, where they found factory jobs and settled with their growing families.

\section{The Watershed of Family Reunification}

Internal migration from Rome to better jobs and housing in northeast Italy's smaller urban centers enabled Bangladeshi men to fulfill the requirements set by Italian migration regulations for family reunification. Interviewees spoke of this move as a "watershed" through which they embarked on married life in a new location where family responsibilities suddenly became paramount. These changes in their family and social status also resulted in changes in their work and leisure rhythms. 
Daily life before family reunification was remembered as irregular and unstructured, reflecting both the nature of the work (especially street-hawking in Rome) and their lack of family ties. Looking back, participants regarded this anomic lifestyle as inadequate, with much time spent "wasted" in pointless leisure and hanging out. Here is how Malek, interviewed in Italy, described the watershed:

Before, I lived with five fellow-countrymen, and every evening, when we came home from work... one day I cooked, one day he cooked, one evening another of us cooked.... So, time passed; I spent my spare time watching television, going around town, always walking around.... Saturday or Sunday with friends, we'd go to the countryside, played cards, spending time together. Now everyone got married, and our families arrived. We have moved to another life; life has changed.

After family reunification, the proximity of their wives and the birth of children meant a fundamental spatio-temporal reorganization of interviewees' behavior, imposing a strict regime on the timing of their daily movements and a change in their patterns of sociality. Malek continued:

In the morning, I wake up at five. I start work at six. I have half an hour to prepare myself and drink coffee, while my wife prepares me something to eat. At half-five I leave home, and I am back at six in the evening. I eat, spend some time with my children and wife; sometimes, we watch television together. Yesterday was Saturday: I only worked in the morning, I came home, we cleaned the house together, we went to the market, then we took a walk to the square. There was a party, with dancing and music.

Other participants were more aware of the different rhythms of the wife's day, typically characterized by loneliness and boredom in an apartment in an industrial suburb while children were at school and husbands were on long shift work and overtime. Rumon, interviewed in Italy where he had been living for 22 years, described gendered daily rhythms in this way:

In Bangladesh she lived one type of life; in Italy she lives another.... The husband works all day, and then in the evening or at night he comes home exhausted. He has dinner and goes to bed; perhaps they are together one hour. The woman is all day alone at home... just passing time.

The quote here reinforces the point made earlier about women's influence on the onward-migration decision. Despite Bangladeshi migration to Italy (and historically to the United Kingdom) being a male-led process, the "behind the scenes" influence of women, especially wives, should not be overlooked. As the earlier quote from Zaeed hinted, the decision-making input of Bangladeshi wives to onward migration is often crucial. Finding themselves deprived of the support of female family members that they had enjoyed in Bangladesh and without opportunities for paid work in 
Italy, their aspirations for a better life in London hinge on joining a much larger Bangladeshi community and the possibility of work, perhaps on a flexible, part-time basis to leave time for family and household responsibilities.

\section{Rhythms of Working Life in the Factories}

Alongside the new pattern of family life, the key temporal frame structuring Bangladeshi workers" life in northeast Italy consisted of the "clocking in" and "clocking off" rhythms of factory production. Nearly all participants worked (or, if in London, had worked) in small and medium-sized industries - part of the linked phenomena of "diffuse industrialization" and "specialized industrial districts" which, since the 1980 s, has turned this part of Italy into the country's most dynamic economic region (Dunford and Greco 2006, 159-168), at least until the recession. Industrial work entailed a number of fundamental changes in the temporalities of work and life, compared to migrants' earlier lives in Rome. The first was a change in employment's security and regularity: from the "arrythmic" precarity of life as a streethawker trying to persuade tourists to buy trinkets, roses, or umbrellas to guaranteed, "rhythmic" employment in factories producing mechanical products, furniture, or leather goods. Here is how Bayazed (London; 24 years in Italy) described his employment situation in Italy:

From Rome, I moved to Treviso [a mid-sized city in northeast Italy], because there was an industrial area there. I found a good job working in a factory .... I worked there from 2000 to 2008; then, with the crisis, that factory closed down, but I immediately found a job in another factory, and I worked there from 2008 until I came to London.

The most important temporal control over Bangladeshi workers' lives in northeast Italy was the "disciplinary rhythm" (Meyer 2008) of regular factory shifts, with fixed days off, usually on weekends and for national and local holidays. Aside from overtime, factory work was organized into two, sometimes three, shifts: the morning shift, the afternoon one, and, for some companies, a night shift. During production peaks, there would be an additional Saturday morning shift. Several participants also described how they integrated their working lives with work for trade union or Bangladeshi associations. Zoir was interviewed in both Italy and London:

In Italy, I worked ten hours per day: from seven in the morning until five, six if I had overtime.... Then I came home and rested. I did five days a week, plus Saturdays, when they asked us for a morning of overtime.... After work, in the late afternoon, two or three days a week, I worked for two hours at the UIL [trade union] .... I did a bit of work as a trade unionist, especially for our community. Then at the weekend I did some work in the association, and I went out shopping with my wife. 
Regular shift times and days off meant that participants' time schedules coincided with those of other workers employed in the factories. Therefore, during free time, it was possible to socialize with other families and neighbors, to participate in associations' activities, and to collectively engage in non-working activities with family and friends. In the closing quote to this subsection, Mintu, interviewed in London, recounted a rich associative life in Italy, including cultural outings to many Italian cities.

Our Bangladeshi associations in Italy organized cultural programs — singing, dancing, talks, in Mantua and also Castel Goffredo [small town in Mantua province] .... We always attended those events.... We also travelled a lot to cities in Italy-Genoa, Bologna, Milan, Venice, Bolzano, Como, Ancona, Rimini, San Marino, Vatican City. With our association we organized social dinners and tour groups at the weekends, we booked a coach, and we all went together.... I enjoyed life in Italy.

\section{An "Integrated” Social Life With Italians?}

While the pattern of communal shift work facilitated social interaction with fellow Bangladeshis, especially for men, some inter-ethnic contact with Italians was also enabled by the regular rhythms of work and community life. In these small and medium-sized industrial settlements, which ranged from just a few thousand to around 30,000 inhabitants, social classes and ethnic groups were mixed together. As Della Puppa and Gelati's (2015) ethnography of one such town demonstrates, the population as a whole had a strong sense of local attachment that favored participation in civic, cultural, and religious events, as well as small-scale spontaneous daily interactions in the street, at the entrance to houses and blocks of flats, in schools, and in public offices. Below, Rafik (interviewed in London), perhaps with nostalgia for those years, remembered his years living in an Italian village of around 4,000 people where, inevitably, people "know each other":

There, I had lots of Italian friends: people who worked with me, but we were not just work colleagues, they were friends. Then I also had friends in the village. It's a small place, everyone knows each other.

In similar fashion, Kayum (London) recalled invitations from neighbors in Italy to share in Christmas events, despite his Muslim faith:

In Italy life was good, but at Christmas it was even more special. It was very joyful with my Italian neighbors ... . I am Muslim, of course, but my Italian neighbors invited me for Christmas, and I enjoyed it a lot, not in church, of course, but in their house, with my wife and children.

From participants' narratives, it seemed that they achieved a somewhat ambivalent integration in Italy: structurally confined to factory work (and elsewhere in Italy, 
to activities such as street-hawking, agricultural labor, and restaurant work) with little opportunity for upward occupational mobility yet at the micro level, despite nativist local politics and widespread "anti-migrant feelings" (Ambrosini 2013; Della Puppa and Gelati 2015), accepted and welcomed by workmates and neighbors. From the many stories of friendship, help, and neighborliness that we collected, here is one that powerfully shows Italians' warm reception of Bangladeshi workers and their families in these small urban centers. We interviewed Ripon twice, first in Italy and then in London. Unusually, his wife also worked in waged labor. Here, in an extract from his Italian interview, he related how an Italian neighbor helped him and his wife with long-term childcare:

Me and my wife are both working, so we had problems taking care of our child, now ten years old.... There is a neighbor that my son calls "granny." She is very kind, very nice. Since my son was born, she has been taking care of him, always helping us, she's so good.... She's Italian, she lives with her sons and daughters. My son stays half the day with her and her family, after school. Then, when we come back home from work, he comes with us to our flat. She collects him from school at mid-day and takes him home to eat with her.

In this way, the neighbor helped the family overcome the arrhythmia of raising young children when both parents were working. When Ripon was interviewed five years later in London, he regretted that such helpful neighborliness was missing in the big city.

\section{Small-Town Urban Structures and Bangladeshi Community Life}

A final element of the time geographies of Bangladeshi family and social life in northeast Italy is the urban structure of these economically dynamic provinces. The towns are morphologically compact, arranged around an ancient downtown (centro storico) where the main public buildings, historic churches, shops, offices, and weekly markets are located - the last of these in the towns' squares. The presence of squares and parks greatly facilitates community sociability and solidarity, especially for immigrant groups' public gatherings, creating an ethnicized re-signification of urban space (La Cecla 1999). Moreover, it is also around the perimeters of the squares and parks, used as meeting places by Bangladeshi families, that Bangladeshi-run commercial activities spring up. This concentration of small ethnic businesses and the polysemous use of these urban micro-spaces can be traced to the functions and layout of villages and small towns in Bangladesh (Della Puppa and Gelati 2015). These parks, squares, and sidewalks in front of the shops and cafés run by Bangladeshi families in Italy became hubs for exchange of information about jobs, decision-making, political discussion, and idle chit-chat-albeit mainly for men. Moreover, the availability of these open spaces meant that migrants, especially men, could socialize among themselves without entering into bars. 
Firstly, we do not go into the bar because we do not drink alcohol, and so here, in the street or the square, we discuss how things are going, about jobs, what is new in the laws on migration, about the home country, what the government there has done ... just talking to our fellow-countrymen. (Abid, 18 years in Italy)

As will be seen in what follows, this dimension of small-town social intimacy and coherent spatial arrangement was lost when participants onward migrated to the very different urban spatiality of a global city.

\section{Times of Work and Social Life in London}

Italian-Bangladeshi men's onward migration from northeast Italy to London resulted from a combination of push-and-pull factors, as noted earlier: first-generation migrants' desire to escape the occupational immobility of factory work; their realization that their Italian-born children's social mobility would be severely constrained in Italy by a combination of economic stagnation and racist attitudes toward people of color; the belief that in London they, and especially their children, would fare better in a more open and buoyant economy and a more multicultural and meritocratic society; the dissatisfaction of some reunited wives concerning their unrewarding lives in small industrial towns; and the postcolonial imaginaries of a cosmopolitan and tolerant capital city. The key facilitating factor was the acquisition of Italian citizenship, which turned the aspiration to onward-migrate into the ability to do so (Carling and Schewel 2017). However, in many cases, the London imagined by these new "European citizens" failed to meet their expectations, and their aspirational moves came with a price, which impacted, above all, the rhythms and freedoms of daily working life and social relations. In a nutshell, participants in London experienced "temporal rupture" and lost what they saw as their "control" over time.

\section{Working in London's Low-Wage Economy}

Italian-Bangladeshis' relocation to London profoundly transformed their lives, above all due to their new jobs' completely different temporal rhythms. Also important were spatial factors: the distances separating their places of residence from their constantly shifting work locations and their more scattered residential distribution across several districts of East London.

As several important studies have revealed (e.g., May et al. 2007; Wills et al. 2010), London's burgeoning economy and deregulated labor market progressed hand-in-hand with an increasingly polarized income distribution and sharp divisions and segmentations in types and levels of remuneration of work. Presaged 30 years ago by Sassen's (1991) depiction of the "global city," these characteristics emerged particularly strongly in London after the turn of the millennium, associated with the Labour Government's "New Deal," and resulting in further deregulation of the economy and large inflows of migrant workers from both within and outside 
the EU. May et al. (2007) use the term "migrant division of labour" to capture the importance of two macro-processes that intersect sharply in London: on the one hand, the model of neoliberal economic management that, through aggressive competition, depresses wages and working conditions in job sectors like construction, cleaning, taxi and delivery driving, and food production, and on the other, people's ongoing necessity and desire to migrate internationally in search of work and improvement in their and their families' lives. These macro-processes, of course, are not unique to London, or to "global" cities in general, but are part and parcel of a much broader intertwining of flexible labor exploitation and social-class reproduction in many parts of the more "developed" world (Smith and Winders 2008). The result across places, however, is an urban labor market divided along ethnicized lives, especially at the bottom end of the labor hierarchy (Wills et al. 2010).

Italian-Bangladeshis were more or less forced into this polarized structure, irrespective of the education, skills, and experience they brought from Bangladesh and Italy. In London's low-skill job market, the options for newly arrived ItalianBangladeshis were limited to insecure employment as mini-cab and delivery-van drivers, security guards, and restaurant and fast-food helpers - all jobs that had unpredictable, unsocial, and hence "arrhythmic" working hours and that were dispersed across different urban spaces. Moreover, these jobs often entailed zero-hour contracts with no social protection or pension entitlements. Here, Razak described the deskilling he was forced to accept when he moved to London, after 24 years in Italy:

Here, I cannot find a good job because I am not formally qualified. I am not considered skilled because I cannot use the skills I acquired in Italy, working in the factory. So it is hard to find a good job, a job that satisfies me .... In Pizza-Hut, where I work now, I am doing deliveries. Here, all you find is jobs of this type. There is not much fear of being unemployed, because you know you can find another job in a short time, but always of this "class"-McDonald, fast-food, jobs like that.

The occupational demotion described by Razak and echoed by many other participants in London had multiple repercussions in relation to self-esteem, gender identity, and family roles. Of course, factory work in Italy was physically draining, but it came with a regular salary and a stable social identity as the "male breadwinner." Work in London, by contrast, failed to match these characteristics and was perceived by participants as inadequate, with respect to both their age and experience and their ability to financially anchor their families, thereby threatening their sense of masculinity.

Many participants stressed the "rupture" in temporal regimes and rhythms between Italy and London (cf. Griffiths et al. 2013). In Italy, as we showed, their involvement in industrial production was organized into regular shifts, generally scheduled on a weekly or monthly basis, which gave both their working lives and their family and leisure times an element of predictability and a sort of 
"eurythmia." Day-to-day and weekly activities could be planned, which facilitated informal social contact, including with local Italians, in various spatio-temporal contexts such as the work canteen, the square, the neighborhood, and outside school entrances. By contrast, participants related how their working lives in London did not permit structured timetables with free (half-)days and instead took on the temporal contours of "just-in-time" or "on call" work undertaken at different times, and sometimes different locations, from one day to the next. Mini-cab drivers' timetables were especially unpredictable, taking them to different urban districts and often outside London. Heterogeneous schedules, places, and work commitments made it difficult to spend time with fellow Bangladeshis and to create friendship networks. Family life was also adversely affected, due to both the variability of work times, including unsocial hours, and the time spent travelling from home or from one job to another.

The abrupt changes in temporal work rhythms between Italy and London recall important concepts from time geography and rhythmanalysis. The empirical examples that follow illustrate the temporal alienation that resulted from London participants' subjection to "strange times" and "asynchronous times" (Cwerner 2001), and passage from a broadly harmonious, structured rhythm of life in Italy to "arrhythmic" (Lefebvre 2004, 16) patterns of their struggle for survival in the flexibilized, deregulated, low-paid employment market of London's service economy. Kobir, who, after 25 years in Italy, worked as a van driver in London, described his work regime's unpredictability. His was a "migrant body" that was flexible, mobile, always available, cheap, and disposable (Smith and Winders 2008, 63-64).

They call me to go to different places, at different times. I have a different shift every day. I work "just in time," I must be very flexible, always available .... They can call me today for tomorrow, or this morning for this afternoon. Now I am sitting in front of you, but if they call me, I must go there in one hour.

The working regimes of those employed as mini-cab drivers, especially when using one of the online platforms that directly connected passengers with drivers, were particularly fragmented, erratic, and often required working at unsocial hours. Arrhythmia existed between migrants' working schedules and the times when they would like, or need, to be with their families or to engage in other social and leisure activities. As the quote from Sherif demonstrates, this unpredictability could sometimes have the benefit of creating unscheduled time with family and children, but in general the taxi-driver's life, with its peaks of demand in the evenings and weekends, did not harmonize well with family life.

Here, there is no timetable. In the morning I wake up at eight, whilst my wife is getting the children ready. At half-eight I leave the house, take the children to school, and then start work. I drive a mini-cab. I work until two or three o'clock, sometimes until four 
o'clock because you never know where you have to go. If you work with a local agency, you know where you are going: before accepting the job, you know where have to go. While if you work with Uber, you do not know beforehand: you accept the call, and the destination comes last. Maybe it turns out you have to go to Cambridge University. However ... then I go home, I take my lunch. I see the children, and in the evening I go out and work a few hours more.

\section{Challenges of Meeting Friends and Community Life}

Italian-Bangladeshis settled almost exclusively in East London, where those Bangladeshis who migrated directly from the home country had already established their large community, initially near London Docks but subsequently extending their sphere of residence eastwards into more suburban areas. East London's urban sprawl, with immigrants from a wide variety of origins - South Asia, Africa, and latterly Eastern Europe - settling into what was traditionally a "white" workingclass series of districts, represented a very different urban spatial context than northeast Italy's compact urban forms. The result was a more challenging setting for meeting up with friends and fellow Bangladeshis. Compared to northeast Italy, therefore, London's social life was more constrained not only due to differing temporal rhythms but also because of London neighborhoods' spatial fragmentation and the much longer travel times involved. Jahan described these practical problems of meeting friends:

To meet together in one place takes a long time. If I want to meet one of my friends, I have to spend one hour to go and one hour to come back.... Sometimes, I would like to meet people because I have a couple of hours of free time, but then I realize I would have to drive or take the bus and it would take too much time just to go to "Caffe Italia" [a café owned by an Italian-Bangladeshi in London] . . and so .... I give up and don't go. When I lived in Italy, I just had to go to Piazza San Paolo, three minutes walking.

A further challenge was London's lack of public open spaces that corresponded to the squares and small parks found in Italian towns, and Britain's colder and rainier climate, which discouraged alfresco sociality, especially in winter. Therefore, interviewees' main meeting places in London were coffee-shops where spending money was compulsory, making the kind of spontaneous, informal, and cost-free socializing enjoyed in Italy impossible.

Hence, compared to Italy, migrant men lost some control over both the location and timing of their work and social interaction, with negative effects on their family life, friendship patterns, and ability to integrate into East London's wider multicultural society. Note that we specify "some control" because we recognize that in Italy their industrial work rhythms were very much dictated by factory owners and the nature of their contracts. In addition to having less opportunity to meet with other Italian-Bangladeshi families that had moved to London, interviewees reported that 
the fragmentation of work time, spatial dispersal of residences, and absence of meeting points also resulted in an almost total lack of contact with the "native" British population and the long-settled Bangladeshi community from Sylhet. Below is a typical account from Rintu (23 years in Italy) of the problems of social contact that Italian-Bangladeshis faced in their London environment.

It's hard to have English friends .... In Italy, I had many Italian friends .... Here, many of us are like me, mini-cab drivers, and British people do not do this.... Here in London, we do not work in factories like in Italy. We work in kitchens or as dishwashers in restaurants, and also there we do not meet English people.... They are outside our circles; there are no chances to meet them. They do "high" jobs in the City; then in the evening, they go with the Underground to their neighborhoods, which are different from ours, so we never meet them. Then there are the lower-class laborers, who spend a lot of time in the pub, but we don't go to the pub and therefore we never meet them either .... For the new generation of Italian-Bangladeshis, our children, who will study and grow up here, it will be different - they will know professionals, at the university, at work, as colleagues. But us, the first generation of Italian-Bangladeshis in London, we do not have these possibilities. We only meet with each other.

The narrowing of Italian-Bangladeshis' social circles in London was also related to the specific characteristics of the neighborhoods where they settled in East London: Tower Hamlets, Newham, and further out in Redbridge and Dagenham. These boroughs are characterized by what Vertovec (2007) calls "super-diversity," implying not just a decreasing proportion of "white" British but also an increasing presence of immigrants from many different parts of the world. While East London has played host to long-established immigrant communities from former British colonies in South Asia, the Caribbean, and Africa, newer arrivals from many other parts of the world (Latin America, China, and Eastern Europe) have transformed the diverse ethnic and social character of these boroughs away from Bangladeshis' imaginaries of a post-imperial Britain where they would feel "at home." Instead, they find themselves living among a diversity of cultures, some of which are alien to their way of life.

\section{"I Come From Bangladesh" vs. "I Come From Sylhet"}

A main stimulus for onward migration from Italy to London was the opportunity to join the largest Bangladeshi community in Europe. However, over 90 percent of British-Bangladeshis trace their origins to the Sylhet district of northeastern Bangladesh (Zeitlyn 2016), whereas the new arrivals from Italy originated from a wider range of mostly central districts, including Dhaka (Della Puppa 2014; Knights and King 1998). Italian-Bangladeshis' hopes that they would become integrated within the wider British-Bangladeshi community in London were somewhat frustrated, and interviewees reported that the relationship between these two communities was 
characterized by mistrust and prejudice that, when unpacked, had multiple origins and layers. First, this problematic relationship can be interpreted as a partial result of the anti-immigrant rhetoric that characterized public debate in the years leading up to the June 2016 "Brexit" vote to leave the European Union. At this time, hostility was turned particularly toward "uncontrolled" immigration from the EU, which allegedly had threatened British national identity, taken jobs away from British workers, and strained housing and welfare services (see Lulle et al. 2019). Thus, one reading of the "gap" between different Bangladeshi elements is that it was an opposition between British citizens of Sylheti origin and Italian/EU citizens:

Most of our countrymen here come from Sylhet. They are not very friendly towards us .... They ask us: "Why did you come here? Go back to Italy!" They think we came here to compete against them. (Zoir)

A more historical layer to this antagonism reflects the Sylhetis' alleged chauvinistic disposition due to the special political and fiscal regime that the British colonial administration granted to the historic Sylhet region (Gardner 1995). Emigration from the region was favored, which in turn, via remittances and investments, accelerated Sylhet's development compared to other parts of the country. Another difference derives from the Sylheti culture and dialect, which are distinctive, fomenting a separatist identity among the Sylheti diaspora (Van Schendel 2009).

To be frank, we don't have much to do with the Sylhetis because they are different .... They get together by themselves.... There are less relationships with them because they are Sylheti and British, and we are Bangladeshi and Italian. They say: "I'm British and this guy is from Italy, so I'm superior." (Shanu)

Finally, the mutual antipathy can be read as an effect of the socio-temporal stratification of the Bangladeshi diaspora's different waves. The first generation of Bangladeshis who migrated to Italy in the late 1980s and the 1990s, including those who onward-migrated to London 15-25 years later, consisted of young men who belonged to the middle and upper-middle classes of Bangladeshi society, with good education and pronunciation of the Bangla language. The Sylhetis and their descendants in London originated from conservative rural areas of Sylhet, were poorly educated, and had their own strong regional dialect (Miah and King 2018). Hence, intra-community frictions in London, and the consequently reduced social contact, reflected this differentiated internalized habitus.

The words of the Italian-Bangladeshi participants presented earlier represent individual perceptions of the British-Sylhetis in London. However, such views undoubtedly reflect both the causes and experiences of partial social isolation and incomplete inclusion, related in turn to different "diasporic times" (Cwerner 2001), and to the constrained times and spaces of opportunity for sociality within East London's multicultural context. Not only are the parts of East London where 
Italian-Bangladeshis have settled ethnically fragmented by different migrant groups arriving from different origins at different times but also the experience of participants reveals the internal schisms within a supposedly homogenous national-origin community.

\section{Conclusion}

As evidenced in our literature review, time is an under-researched and undertheorized dimension of migration and especially of the lived experiences that are temporally enfolded within migration trajectories. Cwerner's (2001) landmark paper on the "times" of migration set the initial theoretical agenda, but detailed empirical studies on the daily life and other periodic temporalities of migrants and their significant others have been slow to emerge and are few in number (e.g., Marcu 2017; Mavroudi et al. 2017; Reid-Musson 2015; Wee et al. 2020). Deploying the theoretical frameworks of Hägerstrand's time geography and Lefebvre's rhythmanalysis, in this article we have comparatively analyzed the contrasting temporalities of work and everyday life of Bangladeshi migrant men in Italy and onward-migrated Italian-Bangladeshis in London. The focus on onward migrants enabled a diachronic comparison of the same migrant group in two contrasting destinations. By focusing on the micro-temporalities of their everyday working, family, and social lives, we have contributed new insights into onward migration as a recently expanding area in global migration dynamics (cf. Ahrens et al. 2016; King and Karamoschou 2019).

Wee et al. $(2020,112)$ make the important point that "rhythms, intimately experienced through the mobile body, are conditioned by the labour market." Our findings go one step further and show that the rhythmic (and arrhythmic) temporalities of migrants' everyday lives are powerfully underscored by the mode of regulation of the labor market and the spatial setting within which migrants' working lives unfold. As we show, in both locations, migrants were restricted to "lower-class" jobs that non-migrants would generally reject, reflecting migrant labor's continuing "reserve army" function within contrasting varieties of contemporary capitalism, but experienced those jobs - and their impacts on family and social life - in fundamentally different ways.

In northeast Italy, migrants' lives were disciplined by the rhythms of factory shifts and, by extension, the economic regime of small- and medium-scale industrial capitalism. Despite this "dictatorial" role of time, participants appreciated their ability to enjoy economically secure lives structured around predictable work patterns, family time, and multiple opportunities for socializing. The small Italian towns where they settled offered convivial spaces in parks and squares for socialization both within and beyond the ethnic community. These concatenated polyrhythms were fused together in a generally harmonious pattern that can be regarded as broadly eurhythmic. Although the main comparison that we make is with ItalianBangladeshi men in London, several participants also drew on memories of their first years in Italy when, as single men, they worked long hours as street-hawkers 
feeding off Rome's tourist economy, creating for themselves a mode of survival in the informal sector's marginal niches.

When Italian-Bangladeshi men moved to London, they experienced a very different set of temporal rhythms, dictated this time by the limits of the jobs they could access in the flexible, casual, low-wage service economy. In this segment of the neoliberalized metropolitan economy, each day's temporality could be different from the next. In contrast to the regular, repetitive, "safe" temporality experienced in Italy, working in London implied an arrhythmic loss of control over time, which became an alienating, disruptive factor in everyday life, compounded by London's enormous size and polycentric dispersion of workplaces. In London, ItalianBangladeshis endured "hard times" in their working and social lives, mortgaging the present against the anticipated more successful "future time" of their yet-to-beadult children.

Furthermore, we found marked contrasts in patterns of "integration." In Italy, the highly managed polyrhythmic "time culture" of small industrial towns created multiple time-space settings for socialization with other Italian-Bangladeshis and with local Italians. At the same time, avenues for upward social and occupational mobility were closed off, for both the first and second generations, by the wider racial prejudices and assumptions imbued in Italian society. In London, everyday temporalities were often in an arrhythmic state, creating obstacles at various levels. Family time was constrained and fragmented; socialization with other Bangladeshis was hindered by a combination of irregular working patterns, spatial distancing, and dialect differences; and social interactions with "white" British people were almost non-existent. Despite these disillusionments and challenges, there was no question of returning to Italy or to Bangladesh, for to do so would be to admit the failure of their transgenerational migration project and aspirations for their children's future.

Although privileging the narrative testimonies of Bangladeshi migrant men, all of them workers, fathers, and "breadwinners" in their nuclear families, enabled us to see and examine how the entanglements of work and life rhythms shaped these migrants' lived realities in different locales, future research could complement this work. In particular, we encourage future research that interrogates the spatiotemporal lived experiences of other population cohorts in the Bangladeshi migrant population, especially women and children. The female perspective is important because it is so often hidden and silenced in studies of male-led migration chains, while uncovering children's voices would reveal the attitudes and achievements, and possible identity struggles, of the cohort of migrants for whom the entire intergenerational migration project, from its origins in Bangladesh via an intermediate yet prolonged stopover in Italy, was designed to produce "success." Onward migration is embedded in a long-term family project of social mobility and economic survival that is also examined in other studies of the "new" middle-class Bangladeshi migration to Europe (Mapril 2011, 2014) and of comparable groups who initially used Southern European countries as an entry-point and staging-post but were then 
pushed northwards by the economic crisis to Britain or Germany (Mas Giralt 2017; McGarrigle and Ascensão 2018; Ramos 2018).

While our article speaks to this wider regional literature on intra-European, crisisrelated onward migration, its other contributions have been twofold. First, we have deployed time geography and rhythmanalysis to explore, in an innovative diachronic comparison, the temporalities of daily work and social life in two geographic settings marked by contrasting urban forms and regulatory regimes of the labor market. Second, we have unfolded the class and generational dynamics of the relatively recent Bangladeshi migration to Italy and onwards to London. As Mapril (2014) has also stressed, it is through geographic mobility, especially to Europe, that young, well-educated Bangladeshi men can earn both economic and symbolic capital to confirm their "modern," even "cosmopolitan" status and, later in their life projects, advance the life-chances of their children. Although migration is itself constitutive of this "middle-classness," as both a resource and a discursive formation (Mapril 2014, 718), the path is far from smooth, and, with no option to go back (for such would be to connote failure), sacrifices must be endured to safeguard the future for their children.

\section{Declaration of Conflicting Interests}

The author(s) declared no potential conflicts of interest with respect to the research, authorship, and/or publication of this article.

\section{Funding}

The author(s) received no financial support for the research, authorship, and/or publication of this article.

\section{ORCID iD}

Francesco Della Puppa (D) https://orcid.org/0000-0003-1437-4719

\section{References}

Adams, C. 1987. Across Seven Seas and Thirteen Rivers: Life Stories of Pioneer Sylheti Settlers in Britain. London: Eastside Books.

Ahrens, J., M. Kelly, and I. van Liempt. 2016. "Free Movement? The Onward Migration of EU Citizens Born in Somalia, Iran, and Nigeria." Population, Space and Place 22(2): 84-98.

Ambrosini, M. 2013. "Fighting Discrimination and Exclusion: Civil Society and Immigration Policies in Italy." Migration Letters 10(3): 313-23.

Becker, H. 1998. Tricks of the Trade: How to Think about Your Research While You're Doing It. Chicago: University of Chicago Press.

Boyle, P., K. Halfacree, and V. Robinson. 1998. Exploring Contemporary Migration. London: Longman.

Carling, J., and K. Schewel. 2018. "Revisiting Aspiration and Ability in International Migration." Journal of Ethnic and Migration Studies 44(6): 945-63.

Centro Studi e Ricerche IDOS. 2017. Dossier Statistico Immigrazione 2017. Rome: IDOS Edizioni. 
Cojocaru, O. 2016. Time and Migration Studies: Theoretical and Methodological Intersections. Centre of Migration Research Working Paper 91/149. Warsaw: Centre of Migration.

Cwerner, S. 2001. "The Times of Migration." Journal of Ethnic and Migration Studies 27(1): 7-36.

Della Puppa, F. 2014. Uomini in Movimento: Il Lavoro della Maschilità fra Bangladesh e Italia. Turin: Rosenberg and Seller.

- 2018. "Ambivalences of the Emotional Logics of Migration and Family Reunification: Emotions, Experiences and Aspirations of Bangladeshi Husbands and Wives in Italy." Identities 25(3): 358-75.

__ , and E. Gelati. 2015. Alte Ceccato: Una Banglatown nel Nordest. Trento: Professionaldreamers.

Della Puppa, F., and D. Sredanovic. 2017. "Citizen to Stay or Citizen to Go? Naturalization, Security and Mobility of Migrants in Italy." Journal of Immigrant and Refugee Studies 15(4): 366-83.

Donaldson, M., R. Hibbins, R. Howson, and B. Pease, eds. 2009. Migrant Men: Critical Studies of Masculinities and the Migration Experience. New York: Routledge.

Dunford, M., and L. Greco. 2006. After the Three Italies: Wealth, Inequality and Industrial Change. Oxford: Blackwell.

Edensor, T. 2010. "Introduction: Thinking about Rhythm and Space." In Geographies of Rhythm, edited by T. Edensor, 1-20. Farnham: Ashgate.

Elden, S. 2004. "Rhythmanalysis: An Introduction." In Rhythmanalysis: Space, Time and Everyday Life, by H. Lefebvre, vii-xv. London: Continuum.

Gallo, E., and F. Scrinzi. 2016. Migration, Masculinities and Reproductive Labour. London: Palgrave.

Gardner, K. 1995. Global Migrants, Local Lives: Migration and Transformation in Rural Bangladesh. Oxford: Oxford University Press.

- 2002. Age, Narrative and Migration: Life History and Life Course amongst Bengali Elders in London. Oxford: Berg.

- 2006. "The Transnational Work of Kinship and Caring: Bengali-British Marriages in Historical Perspective." Global Networks 6(3): 323-39.

Glennie, P., and N. Thrift. 2009. Shaping the Day: A History of Timekeeping in England and Wales 1300-1800. Oxford: Oxford University Press.

Griffiths, M., A. Rogers, and B. Anderson. 2013. Migration, Time and Temporalities: Review and Prospect. COMPAS Research Resources Paper. Oxford: University of Oxford.

Hägerstrand, T. 1975. "Space, Time and Human Conditions." In Dynamic Allocation of Urban Space, edited by A. Karlqvist, L. Lundqvist, and F. Snickers, 3-12. Farnborough: Saxon House.

1982. "Diorama, Path and Project." Tijdschrift voor Economische en Sociale Geografie 73(6): 323-39.

-1985. "Time-Geography: Focus on the Corporeality of Man, Society and Environment." In The Science and Praxis of Complexity, 193-216. Tokyo: United Nations University Press. 
Hansen, T. 2014. "Migration, Religion and Post-Imperial Formations." Global Networks 14(3): 273-90.

King, K., and K. B. Newbold. 2007. "Onward Migration to the United States by Canadian Immigrants between 1995 and 2000.” International Migration Review 41(4): 909-29.

King, R., and C. Karamoschou. 2019. "Fragmented and Fluid Mobilities: The Role of Onward Migration in the New Map of Europe.” Migracijske i Etničke Teme 35(2): 141-69.

King, R., and M. Knights. 1994. "Bangladeshis in Rome: A Case of Migratory Opportunism." In Population Migration and the Changing World Order, edited by W. Gould and A. M. Findlay, 127-43. Chichester: Wiley.

King, R., and A. Lulle. 2015. "Rhythmic Island: Latvian Migrants in Guernsey and their Enfolded Patterns of Space-Time Mobility." Population, Space and Place 21(7): 599-611.

Kipfer, S., K. Goonewardena, C. Schmid, and R. Milgrom. 2008. "On the Production of Henri Lefebvre.” In Space, Difference, Everyday Life: Reading Henri Lefebvre. Edited by K. Goonewardena, S. Kipfer, R. Milgrom, and C. Schmid, 1-23. New York: Routledge.

Knights, M., and R. King. 1998. "The Geography of Bangladeshi Migration to Rome." International Journal of Population Geography 4(4): 299-321.

La Cecla, F. 1999. Introduzione all'Urbanistica Multietnica. Milan: FrancoAngeli.

Lefebvre, H. 1991. The Production of Space. Malden, MA: Blackwell.

1996. Writings on Cities. Malden, MA: Blackwell.

2004. Rhythmanalysis: Space, Time and Everyday Life. London: Continuum. 2014. Critique of Everyday Life. London: Verso.

Lulle, A., R. King, V. Dvorakova, and A. Szkudlarek. 2019. "Between Disruptions and Connections: 'New' European Union Migrants in the United Kingdom Before and After Brexit.” Population, Space and Place 25(1): e2200.

Mapril, J. 2011. "The Patron and the Madman: Migration, Success and the (In)visibility of Failure amongst Bangladeshis in Portugal.” Social Anthropology 19(3): 288-96.

- 2014. "The Dreams of Middle Class: Consumption, Life-course and Migration between Bangladesh and Portugal.” Modern Asian Studies 48(3): 693-719.

Malmberg, G. 1997. "Time and Space in International Migration." In International Migration, Immobility and Development, edited by T. Hammar, G. Brochmann, K. Tamas and T. Faist, 21-48. Oxford: Berg.

Marcu, S. 2017. "Tears of Time: A Lefebvrian Rhythmanalysis Approach to Explore the Mobility Experiences of Young Eastern Europeans in Spain." Transactions of the Institute of British Geographers 42(3): 405-16.

Mas Giralt, R. 2017. "Onward Migration as a Coping Strategy? Latin Americans Moving from Spain to the UK post-2008." Population, Space and Place 23(3): e2017.

Mavroudi, E., B. Page, and A. Christou, eds. 2017. Timespace and International Migration. Cheltenham: Edward Elgar.

May, J., J. Wills, K. Datta, Y. Evans, J. Herbert, and C. Mcllwaine. 2007. "Keeping London Working: Global Cities, the British State and London's New Migrant Division of Labour." Transactions of the Institute of British Geographers 32(2): 151-67. 
McGarrigle, J., and E. Ascensão. 2018. "Emplaced Mobilities: Lisbon as a Translocality in the Migration Journeys of Punjabi Sikhs to Europe." Journal of Ethnic and Migration Studies 44(5): 809-28.

Meyer, K. 2008. "Rhythms, Streets, Cities." In Space, Difference, Everyday Life: Reading Henri Lefebvre, edited by K. Goonerwardena, S. Kipfer, R. Milgrom and C. Schmid, 147-60. New York: Routledge.

Miah, Md. F., and R. King. 2018. "Memoryscapes of the Homeland by Two Generations of British-Bangladeshis." In Memory, Tourism and Migration, edited by S. Marschall, 213-33. London: Routledge.

Novak, P. 2017. "Border Rhythms." In Timespace and International Migration, edited by E. Mavroudi, B. Page and A. Christou, 61-76. Cheltenham: Edward Elgar.

Pred, A. 1977. "The Choreography of Existence: Comments on Hägerstrand's Time Geography.” Economic Geography 53(2): 207-21.

1981. "Production, Family and 'Free-Time' Projects: a Time-Geographic Perspective on Individual and Societal Change in Nineteenth-Century US Cities." Journal of Historical Geography 7(1): 3-36.

Priori, A. 2012. Romer Probashira: Reti Sociali e Itinerari Transnazionali Bangladesi a Roma. Rome: Meti.

Ramos, C. 2018. "Onward Migration from Spain to London in Times of Crisis: The Importance of Life-course Junctures in Secondary Migrations." Journal of Ethnic and Migration Studies 44(11): 1841-57.

Reid-Musson, E. 2018. "Intersectional Rhythmanalysis: Power, Rhythm, and Everyday Life." Progress in Human Geography 42(6): 881-97.

Robertson, S. 2015. "The Temporalities of International Migration: Implications for Ethnographic Research." In Social Transformation and Migration: National and Local Experiences in South Korea, Turkey, Mexico and Australia, edited by S. Castles, D. Ozkul and M.A. Cubas, 45-60. Basingstoke: Palgrave Macmillan.

Sacchetto, D., and F. A. Vianello. 2016. "Migrant Workers' Routes to the Informal Economy during the Economic Crisis: Structural Constraints and Subjective Motivations." Prakseologia 158: 299-322.

Sassen, S. 1991. The Global City: New York, London, Tokyo. Princeton, NJ: Princeton University Press.

Smith, B. E., and J. Winders. 2008. “'We're Here To Stay': Economic Restructuring, Latino Migration and Place-Making in the US South." Transactions of the Institute of British Geographers 33(1): 60-72.

Thomson, E. P. 1967. "Time, Work Discipline and Industrial Capitalism." Past and Present 38: 56-97.

Thrift, N., and A. Pred. 1981. "Time-Geography: A New Beginning." Progress in Human Geography 5(2): 277-86.

Van Schendel, W. 2009. A History of Bangladesh. Cambridge: Cambridge University Press. Veneto Lavoro. 2012. Un Lento Dimagrimento. Rapporto 2012. Milan: FrancoAngeli.

2014. Discesa Finita? Crisi al Sesto Anno: Assottigliati ancora Posti di Lavoro e Risorse Imprenditoriali. Rapporto 2014. Milan: FrancoAngeli. 
Vertovec, S. 2007. "Super-Diversity and its Implications." Ethnic and Racial Studies 30(6): $1024-54$.

Wee, K., C. Goh, and B. S. A. Yeoh. 2020. "Choreographing the Rhythms of Encounter in Singapore's Maid Agencies." Transactions of the Institute of British Geographers 45(1): 155-67.

Wills, J., K. Datta, Y. Evans, J. Herbert, J. May, and C. McIlwaine. 2010. Global Cities at Work: New Migrant Divisions of Labour. London: Pluto.

Winders, J. 2014. "New Immigration Destinations in Global Context." International Migration Review 48(S1): S149-79.

Wojnicka, K., and P. Pustulka. 2019. "Research on Men, Masculinities and Migration: Past, Present and Future." Norma: International Journal for Masculinity Studies 14(2): 91-95.

Zeitlyn, B. 2016. Transnational Childhood: British Bangladeshis, Identities and Social Change. Basingstoke: Palgrave Macmillan. 